\title{
Exploration of novel inorganic compounds using diffractometry and microscopy toward innovative functions
}

\author{
Koichiro FUKUDA ${ }^{\dagger}$ \\ Department of Materials Science and Engineering, Nagoya Institute of Technology, Nagoya 466-8555, Japan
}

\begin{abstract}
The author will briefly review the recent progress and future perspective on the research topics of (i) highly $c$-axis-oriented polycrystals of lanthanum silicate oxyapatite in the pseudo-binary system $\mathrm{La}_{2} \mathrm{SiO}_{5}-\mathrm{La}_{2} \mathrm{Si}_{2} \mathrm{O}_{7}$, (ii) homologous layered carbides in the system $\mathrm{Zr}-\mathrm{Y}-\mathrm{Si}-\mathrm{Al}-\mathrm{C}$, (iii) layered oxycarbonitrides in the system Al-Si-O-C-N, (iv) crystal structures and ordered atom arrangements in SiAION polytypoids, and (v) disordered crystal structure of $\mathrm{Al}_{3} \mathrm{O}_{3.5} \mathrm{C}_{0.5}$. The crystal structures were necessarily expressed by the split-atom models for the layered oxycarbonitrides and SiAION polytypoids, indicating that each of these compounds was composed of domains related by merohedral twinning. With $\mathrm{Al}_{3} \mathrm{O}_{3.5} \mathrm{C}_{0.5}$ the antiphase domains (APDs) were observed, which were formed by the high-low phase transition involving loss of translational symmetry elements. The formation mechanisms of merohedral and pseudo-merohedral twin domains as well as APDs will be discussed in detail.
\end{abstract}

(02015 The Ceramic Society of Japan. All rights reserved.

Key-words: Functional materials, X-ray diffraction, Optical microscopy, Electron microscopy, Crystal structures, Disordered structures

[Received March 23, 2015; Accepted May 31, 2015]

\section{Introduction}

The demand for the development of new innovative materials is ever increasing. The syntheses of new materials and subsequent characterization of their crystal structures and microtextures are indispensable for the advancement in the field of materials science and engineering. Under the circumstances the author's recent research has mainly focused on the oxide-ion conductors as electrolytes and the thermoelectric conversion materials. The electrolytes for solid oxide fuel cells (SOFCs) working at intermediate temperatures (873-973 K) are advantageous than the widely used yttria stabilized zirconia which operates as electrolyte at the relatively high temperatures (1023-1073 K). Thus, lanthanum silicate oxyapatite (LSO) is among the most promising oxide-ion conductors because it exhibits relatively high ionic conductivity at around $873 \mathrm{~K}^{\left.1{ }^{1)}, 2\right)}$ Thermoelectric materials with high efficiency of energy conversion are of interest for applications as heat pumps and power generators. Low-dimensional materials consisting of, for example, conducting two-dimensional (2D) layers are adequate to thermoelectric energy conversion. ${ }^{3)-8)}$ The homologous layered carbides in the system $\mathrm{Zr}-\mathrm{Y}-\mathrm{Si}-\mathrm{Al}-\mathrm{C}$ can be regarded as the natural superlattice quantum-well materials. Hence, they are one of the promising materials with $n$-type thermoelectricity.

Phase transitions of inorganic compounds often induce intracrystalline microstructures. ${ }^{9)}$ When the low-symmetry phase is a subgroup of the high-symmetry phase, two basically different types of microstructures result (Fig. 1). They are twin domains and antiphase domains (APDs). The twin domains arise from the loss of a point symmetry element. When the high- and lowsymmetry phases have the same Bravais lattices, the resulting twinning is by merohedry. On the other hand, the pseudomerohedral twins will be formed by the change in the Bravais

Corresponding author: K. Fukuda; E-mail: fukuda.koichiro@ nitech.ac.jp

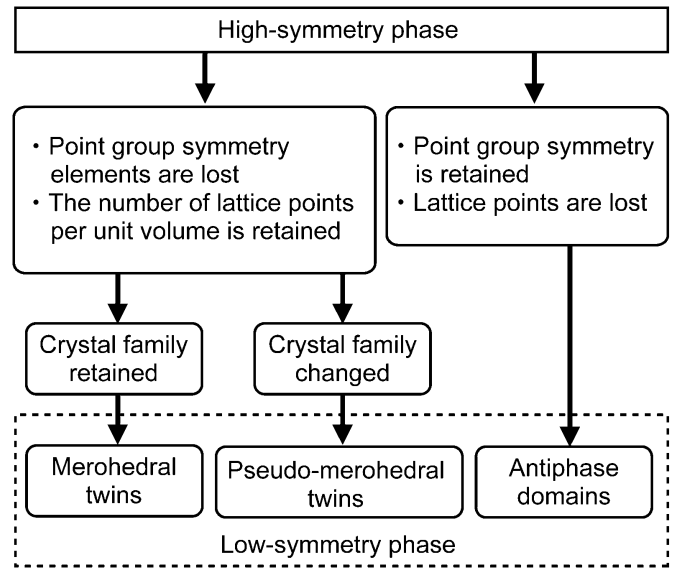

Fig. 1. Three types of intra-crystalline microstructures of merohedral twins, pseudo-merohedral twins and antiphase domains induced by highlow phase transition. Modified from Fig. 12-1 by Nord, Jr. (1992). ${ }^{9}$

lattice. The latter twinning is rather easily detectable because the adjacent twin domains produce slightly split diffraction spots. The APDs are formed by the transitions in which the point group remains the same but the number of lattice points per unit volume is reduced and/or the translational symmetry elements are lost. The displacement vectors relating the domains are the vectors from the origin to the lost lattice points. The APD boundaries are made visible in transmission electron microscopy (TEM) because of a change in the phase of the electron beam as it crosses the boundary. The formation of APDs is usually accompanied by the appearance of extra reflections in the electron diffraction pattern.

In the present paper, the author reviewed the recent progress and future perspective on the research topics of (i) highly $c$-axisoriented polycrystalline LSO, (ii) homologous carbides in the system $\mathrm{Zr}-\mathrm{Y}-\mathrm{Si}-\mathrm{Al}-\mathrm{C}$, (iii) layered oxycarbonitrides in the system $\mathrm{Al}-\mathrm{Si}-\mathrm{O}-\mathrm{C}-\mathrm{N}$, (iv) crystal structures of SiAlON poly- 
typoids, and (v) materials in the system $\mathrm{Al}_{2} \mathrm{O}_{3}-\mathrm{Al}_{4} \mathrm{C}_{3}$. The typical experimental procedures used in the relevant studies consist of syntheses of new inorganic materials, characterization of crystal structures and microtextures, and characteristics evaluation of the compounds.

\section{Methodology}

\subsection{Diffractometry}

The single-crystal X-ray diffraction (XRD) is definitely one of the most powerful methods to determine the crystal structures of inorganic compounds. However, the relatively large single crystals with sufficiently high crystallinity are required, which sometimes makes it unable to apply this method for the precise structural characterization. Cases where single-crystal specimens are not available, we have an alternative technique of powder diffractometry. The X-ray powder diffraction (XRPD) method has made remarkable progress in recent years. The advances in the field of crystal-structure analysis from XRPD data have enabled us to investigate the structural details that had not been introduced into the structural models. In order to disclose the structural details, combined use of a maximum-entropy method (MEM) ${ }^{10)}$ and a MEM-based pattern fitting (MPF) method ${ }^{11)}$ is employed. The Rietveld ${ }^{12)}$ and MEM analyses are insufficient to readily determine charge densities because the observed structure factors, $F_{\mathrm{o}}$ (Rietveld), are biased toward the structural models assuming intensity partitioning of the overlapped reflections. The subsequent MPF method reduces the bias as much as possible, giving it advantages over the classical Fourier method. Thus, the MEM and MPF analyses are alternately repeated until the reliability indices no longer decrease. ${ }^{13)}$ Crystal structures are represented not by structural parameters but by three-dimensional electrondensity distributions (EDDs) in MPF. The sophisticated computer programs are available for Rietveld refinement (RIETA-FP) ${ }^{14)}$ MEM analysis (Dysnomia), ${ }^{15)}$ and visualization of structural models and corresponding EDDs (VESTA). ${ }^{16)}$

\subsection{Microscopy}

Optical methods of examining transparent inorganic compounds with the polarizing microscope have an overriding importance not only in mineralogy and petrology but also in materials science and engineering. ${ }^{17)}$ Even today the relevant method retains its unique position as the most useful characterization technique. The microscopic examination is essential for the preliminary identification of constituent phases and for the determination of optical properties, including the deduction of optical axis orientation. The crystals with hexagonal symmetry, such as LSO with the space group $P 6_{3} / m$, are optically uniaxial. Hence, the optical axis of LSO exactly coincides with the crystallographic $c$-axis. When we observe the extinction behavior of the highly $c$-axis oriented LSO polycrystal, each of the constituent crystal grains will come to the extinction position at the same time.

TEM is normally used as a determinative tool in the identification of fine-scale materials. The microscopists are, as the high level of expertise, required to be familiar with diffraction theory as well as the origin of contrast effect since the microscopy and diffractometry are complementary methods. It is sometimes difficult for XRPD solely to determine the unit cells of unknown structures. Under the circumstances, the selected-area diffraction patters obtainable by TEM can be essential to the solution strategy. The lattice images, the light and dark fringe patterns of which are consistent with the atom arrangements, are also helpful for the crystal-structure determination.

\section{Discussion}

\subsection{Syntheses and oxide-ion conductivity of highly $c$-axis-oriented polycrystals of lanthanum sili- cate oxyapatite}

Nakayama et al. have paid much attention to LSO as a promising electrolyte of SOFCs because of the relatively high oxide-ion conductivity at moderate temperatures as well as at low oxygen partial pressures. ${ }^{1), 2)}$ The general formula of LSO is expressed by $\mathrm{La}_{9.33+2 x} \mathrm{Si}_{6-y} \mathrm{O}_{26+3 x-2 y}$, where $x$ and $y$ represent, respectively, the amounts of excess $\mathrm{La}_{2} \mathrm{O}_{3}$ component and $\mathrm{Si}$ deficiency. ${ }^{18)}$ The oxide-ion conductivity is much higher along the $c$-axis than perpendicular to this direction, hence we prepared the $c$-axis-aligned polycrystalline LSO using a reactive diffusion technique. ${ }^{18)-20)}$ This technique is epochal in that it is unnecessary for the complicate procedures nor special equipments, both of which are normally required to produce ceramics with grainoriented microtextures; the popular texturing methods include the templated grain growth process, pressing at high temperatures (hot pressing), applying magnetic field and utilizing centrifugal force. ${ }^{21-23)}$ These fabrication processes are rather complex, and also, the orientation degrees of the textured ceramics are not always satisfactory.

We successfully prepared the grain-aligned polycrystalline LSO by isothermal heating of the diffusion couples consisting of $\mathrm{La}_{2} \mathrm{SiO}_{5}$ and $\mathrm{La}_{2} \mathrm{Si}_{2} \mathrm{O}_{7}$ at $1873 \mathrm{~K}$ for $50-100 \mathrm{~h}$. The Si-deficient LSO has been for the first time discovered in the annealed sandwich-type diffusion couple of $\mathrm{La}_{2} \mathrm{SiO}_{5} / \mathrm{La}_{2} \mathrm{Si}_{2} \mathrm{O}_{7} / \mathrm{La}_{2} \mathrm{SiO}_{5}$ [Fig. 2(a).$^{20)}$ The annealed couple was mechanically processed, and the thin-plate electrolyte consisting of the grain-aligned polycrystal was obtained, the chemical formula of which was expressed by $\mathrm{La}_{9.50} \mathrm{Si}_{5.87} \mathrm{O}_{26}(x=0.087$ and $y=0.130)$. The highly $c$-axis-oriented polycrystal of oxygen stoichiometric LSO with $x=y=0\left(\mathrm{La}_{9.33} \mathrm{Si}_{6} \mathrm{O}_{26}\right)$ was prepared by the heat treatment of the reverse sandwich-type diffusion couple of $\mathrm{La}_{2} \mathrm{Si}_{2} \mathrm{O}_{7} /$ $\mathrm{La}_{2} \mathrm{SiO}_{5} / \mathrm{La}_{2} \mathrm{Si}_{2} \mathrm{O}_{7}$ [Fig. 2(b)]. ${ }^{19)}$ The oxide-ion conductivity at $873 \mathrm{~K}$ along the $c$-axis was $4.2 \times 10^{-2} \mathrm{~S} / \mathrm{cm}$ for the Si-deficient LSO, which was $\sim 2.5$ times higher than that of the oxygen

(a)
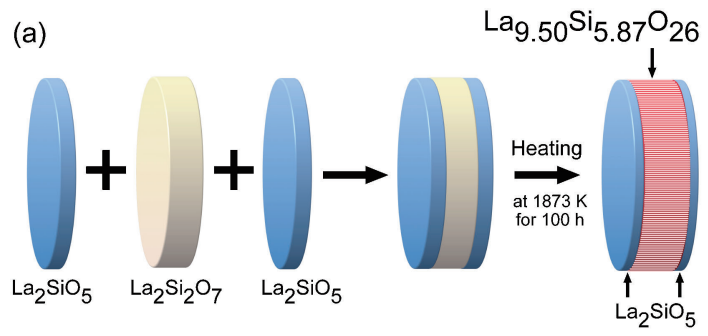

(b)
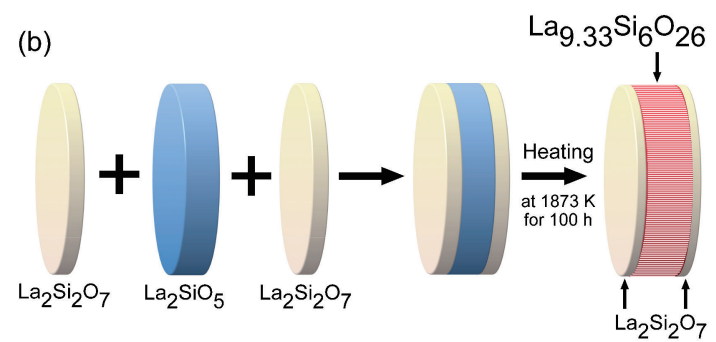

Fig. 2. Syntheses of highly $c$-axis-oriented lanthanum silicate oxyapatite polycrystals by isothermal heating of diffusion couples of (a) $\mathrm{La}_{2} \mathrm{SiO}_{5} / \mathrm{La}_{2} \mathrm{Si}_{2} \mathrm{O}_{7} / \mathrm{La}_{2} \mathrm{SiO}_{5}$ and (b) $\mathrm{La}_{2} \mathrm{Si}_{2} \mathrm{O}_{7} / \mathrm{La}_{2} \mathrm{SiO}_{5} / \mathrm{La}_{2} \mathrm{Si}_{2} \mathrm{O}_{7}$ at $1873 \mathrm{~K}$ for $100 \mathrm{~h}$. 


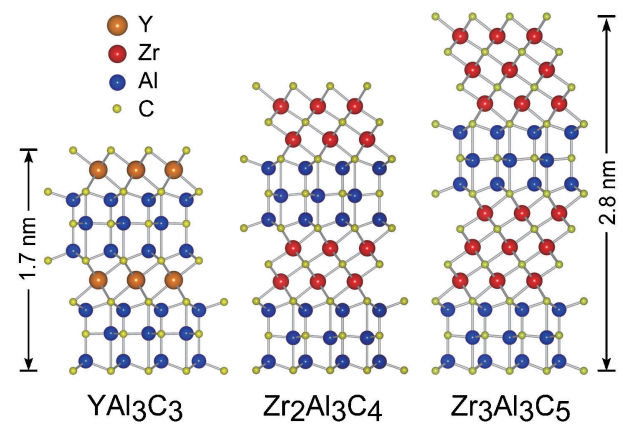

Fig. 3. Atomic configurations in $(M \mathrm{C})_{l} \mathrm{Al}_{3} \mathrm{C}_{2}(M=\mathrm{Zr}$ or $\mathrm{Y})$ with $l=1$ $\left(\mathrm{YAl}_{3} \mathrm{C}_{3}\right), 2\left(\mathrm{Zr}_{2} \mathrm{Al}_{3} \mathrm{C}_{4}\right)$ and $3\left(\mathrm{Zr}_{3} \mathrm{Al}_{3} \mathrm{C}_{5}\right)$.

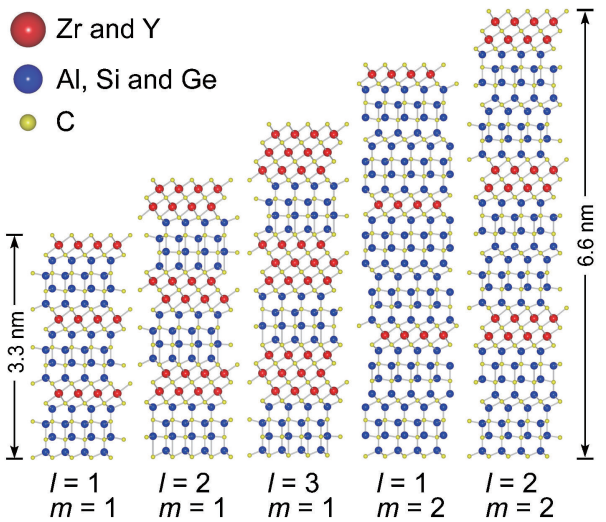

Fig. 4. Atomic configurations in $(M C)_{l}\left(T_{4} \mathrm{C}_{3}\right)_{m}(M=\mathrm{Zr}$, $\mathrm{Y}$ and/or $\mathrm{Hf}$, $T=\mathrm{Al}, \mathrm{Si}$ and/or Ge) with $1 \leq l \leq 3$ and $1 \leq m \leq 2$.

stoichiometric LSO. For further detailed information on the texturing method of reactive diffusion and the oxide-ion conductivity of the $c$-axis-oriented polycrystalline LSO, the readers can refer to the author's recent review paper. ${ }^{24)}$

\subsection{Syntheses and advanced features of new homologous layered carbides in the system $\mathrm{Zr}-\mathrm{Y}-\mathrm{Si}-\mathrm{Al}-\mathrm{C}$}

In the ternary system $M-\mathrm{Al}-\mathrm{C}(M=\mathrm{Zr}, \mathrm{Y}, \mathrm{Sr}$ or $\mathrm{U})$, the three types of homologous layered carbides, the general formula of which is $(M \mathrm{C})_{l} \mathrm{Al}_{3} \mathrm{C}_{2}$ with $l=1,2$ and 3 , were reported before 2007..$^{25)-31)}$ The crystal structure of $\mathrm{YAl}_{3} \mathrm{C}_{3}(l=1)$, for example, is hexagonal with space group $P 6_{3} m c(Z=2)$ and the unit-cell dimensions are $a=0.34216 \mathrm{~nm}$ and $c=1.7282 \mathrm{~nm}$. The other two types of compounds, $\mathrm{Zr}_{2} \mathrm{Al}_{3} \mathrm{C}_{4}(a=0.33468 \mathrm{~nm}$ and $c=$ $2.2239 \mathrm{~nm})$ and $\mathrm{Zr}_{3} \mathrm{Al}_{3} \mathrm{C}_{5}(a=0.3346 \mathrm{~nm}$ and $c=2.7649 \mathrm{~nm})$, also belong to the same space group. ${ }^{25), 26), 30)}$ These compounds show intergrowth structures with the $\left[M \mathrm{C}_{2}\right]$ thin slabs separated by the $\mathrm{Al}_{4} \mathrm{C}_{3}$-type $\left[\mathrm{AlC}\right.$ layers (Fig. 3). ${ }^{31)}$

In 2007, we have discovered a new quaternary layered carbide $\mathrm{Zr}_{2}(\mathrm{Al}, \mathrm{Si})_{4} \mathrm{C}_{5}$, which is trigonal (space group $R 3 m$ and $Z=3$ ) with the unit-cell dimensions of $a=0.33106 \mathrm{~nm}$ and $c=4.0945$ $\mathrm{nm} .{ }^{32)}$ Since then we successively reported the five types of new homologous compounds in total, the general formula of which is expressed by $(M \mathrm{C})_{l}\left(T_{4} \mathrm{C}_{3}\right)_{m}(M=\mathrm{Zr}$, Y and/or $\mathrm{Hf}, T=\mathrm{Al}$, $\mathrm{Si}$ and/or Ge) with $1 \leq l \leq 3$ and $1 \leq m \leq 2$ (Fig. 4). ${ }^{32)-38)}$ The crystal structures were determined by the combined use of XRPD and TEM. These compounds show a close relationship in crystal structure and chemical composition; the formula requires two integers $l$ and $m$ that can be changed independently, and hence

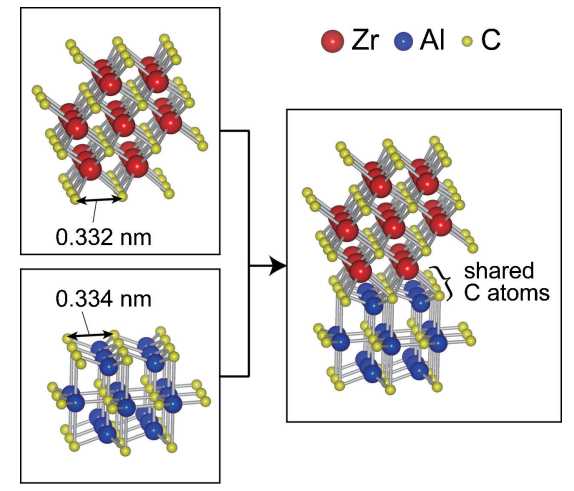

Fig. 5. A part of the layered structure of $\left(\mathrm{ZrC}_{l}\left(\mathrm{Al}_{4} \mathrm{C}_{3}\right)_{m}\right.$ with $l=3$ and $m=1$, demonstrating the two-dimensional networks of $\mathrm{C}$ atoms at the boundary between NaCl-type $\left[\mathrm{Zr}_{3} \mathrm{C}_{4}\right]$ layer and $\mathrm{Al}_{4} \mathrm{C}_{3}$-type $\left[\mathrm{Al}_{4} \mathrm{C}_{4}\right]$ layer.

causes evolution of the structure in two different dimensions. The atom arrangements are regarded as intergrowth structures consisting of the $\mathrm{NaCl}$-type $\left[M_{l} \mathrm{C}_{l+1}\right]$ layers separated by the $\mathrm{Al}_{4} \mathrm{C}_{3^{-}}$ type $\left[T_{4 m} \mathrm{C}_{3 m+1}\right]$ layers. These two types of structural elements share the two-dimensional networks of carbon atoms at their boundaries; the $\mathrm{C}-\mathrm{C}$ distances are about $0.333 \mathrm{~nm}$ (Fig. 5). The $\mathrm{C}-\mathrm{C}$ distance of $\mathrm{ZrC}$ is $0.330 \mathrm{~nm}[=a(\mathrm{ZrC}) / \sqrt{ } 2]$ and that of $\mathrm{Al}_{4} \mathrm{C}_{3}$ is $0.334 \mathrm{~nm}\left[=a\left(\mathrm{Al}_{4} \mathrm{C}_{3}\right)\right]$, where $a(\mathrm{ZrC})$ and $a\left(\mathrm{Al}_{4} \mathrm{C}_{3}\right)$ are the $a$-axis lengths of $\mathrm{ZrC}$ and $\mathrm{Al}_{4} \mathrm{C}_{3}$ crystals, respectively. These distances are close to each other, and also to those of the carbonatom networks in $(M \mathrm{C})_{l} \mathrm{Al}_{3} \mathrm{C}_{2}$ and $(M \mathrm{C})_{l}\left(T_{4} \mathrm{C}_{3}\right)_{m}$. Thus, the closeness of the $\mathrm{C}-\mathrm{C}$ distances between the $\mathrm{ZrC}$ and $\mathrm{Al}_{4} \mathrm{C}_{3}$ crystals, being expressed by the equation $a(\mathrm{ZrC}) / \sqrt{ } 2 \approx a\left(\mathrm{Al}_{4} \mathrm{C}_{3}\right)$, would be the principal reason for the formation of these layered carbides. $^{26), 31)-38)}$

The layered carbides aforementioned can be regarded as the natural superlattice quantum-well materials since all of these crystal structures are characterized by the alternative stacking of the electric conductive $\left[M_{l} \mathrm{C}_{l+1}\right]$ layers and rather insulative $\left[T_{4 m} \mathrm{C}_{3 m+1}\right]$ layers. ${ }^{39)}$ The advantage of the low dimensionality can be interpreted in terms of the carrier confinement effect in the 2D layers, which leads to an enlarged absolute value of the Seebeck coefficient $(S)$ compared to the materials with three dimensional conducting paths. ${ }^{3)-8)}$ In addition, the 2D layered materials are expected to have relatively low thermal conductivity $(\kappa)$ due to phonon scattering at layer interfaces. Hence, the materials with layered nanostructures could show high performance of thermoelectricity, which is quantified by a figure of merit $S^{2} \sigma / \kappa$, where $\sigma$ is electrical conductivity. Thus, the layered carbides have prospects for application of thermoelectric power generators. Actually, we determined the temperature dependence of thermoelectric power factor $\left(S^{2} \sigma\right)$ from the $\sigma$ - and $S$-values for $\mathrm{Zr}_{2}(\mathrm{Al}, \mathrm{Si})_{4} \mathrm{C}_{5}, \mathrm{Zr}_{3}(\mathrm{Al}, \mathrm{Si})_{4} \mathrm{C}_{6}, \mathrm{Zr}_{2} \mathrm{Al}_{3} \mathrm{C}_{4}, \mathrm{Zr}_{3} \mathrm{Al}_{3} \mathrm{C}_{5}$ and $\mathrm{YAl}_{3} \mathrm{C}_{3}$ (Fig. 6). ${ }^{31)-33)}$ The signs of $S$ were necessarily negative for these compounds irrespective of temperature, suggesting the predominant negative mobile charge carriers. The absolute value of $S$ was the largest for $\mathrm{YAl}_{3} \mathrm{C}_{3}$ among the five types of layered carbides, which steadily increased to $112 \mu \mathrm{V} / \mathrm{K}$ with increasing temperature up to $1073 \mathrm{~K}$ [Fig. 6(b)]. ${ }^{32)}$ Accordingly, the intergrowth structure with the thinner electroconductive layer would be more favorable for thermoelectric power generation. The sintered specimens examined were necessarily composed of randomly grainoriented polycrystals. The grain alignment could further increase the $\sigma$-values and consequently improve the $S^{2} \sigma$-values. 

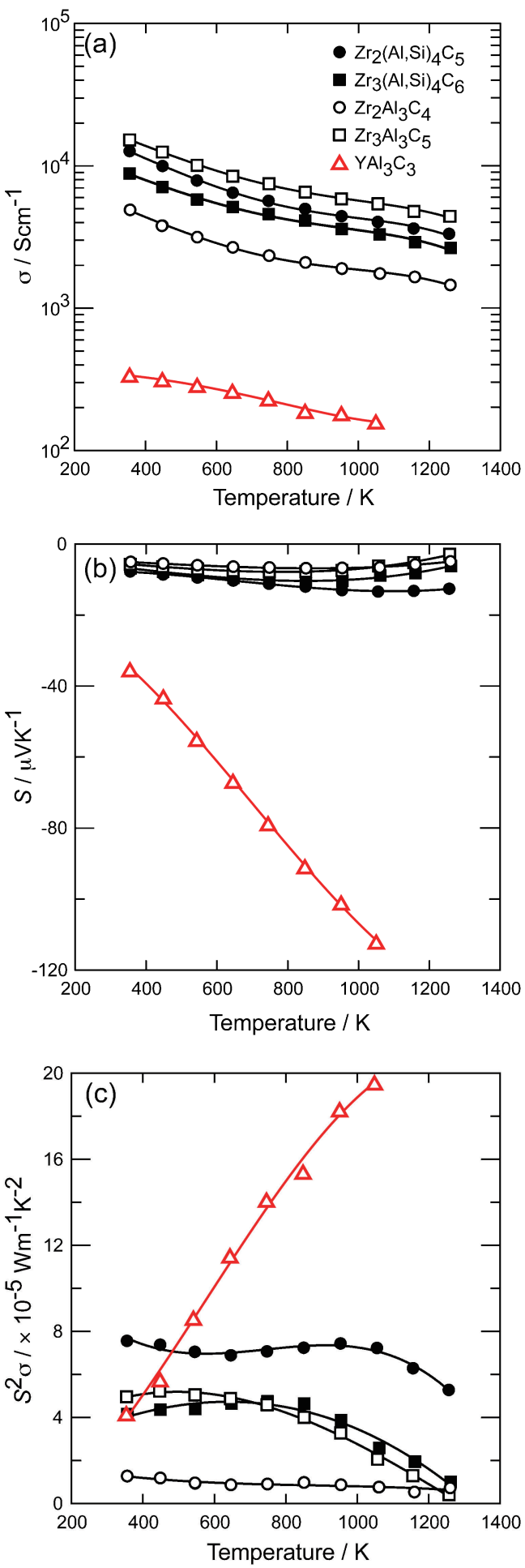

Fig. 6. Temperature dependences of (a) electrical conductivity $\sigma$, (b) Seebeck coefficient $S$ and (c) thermoelectric power factor $S^{2} \sigma$ for $\mathrm{Zr}_{2}(\mathrm{Al}, \mathrm{Si})_{4} \mathrm{C}_{5}, \mathrm{Zr}_{3}(\mathrm{Al}, \mathrm{Si})_{4} \mathrm{C}_{6}, \mathrm{Zr}_{2} \mathrm{Al}_{3} \mathrm{C}_{4}, \mathrm{Zr}_{3} \mathrm{Al}_{3} \mathrm{C}_{5}$ and $\mathrm{YAl}_{3} \mathrm{C}_{3}$.

\subsection{Discovery and characterization of five types of new layered oxycarbonitrides in the system $\mathrm{Al}-\mathrm{Si}-\mathrm{O}-\mathrm{C}-\mathrm{N}$}

In the system $\mathrm{Al}_{4} \mathrm{C}_{3}-\mathrm{SiC}$, the five types of aluminosilicon carbides, $\mathrm{Al}_{4} \mathrm{SiC}_{4}, \mathrm{Al}_{4} \mathrm{Si}_{2} \mathrm{C}_{5}, \mathrm{Al}_{4} \mathrm{Si}_{3} \mathrm{C}_{6}, \mathrm{Al}_{4} \mathrm{Si}_{4} \mathrm{C}_{7}$ and $\mathrm{Al}_{8} \mathrm{SiC}_{7}$, were reported during 1961-1989. ${ }^{40-44)}$ In 1966, the structural models, being isomorphous with those of aluminosilicon carbides, were

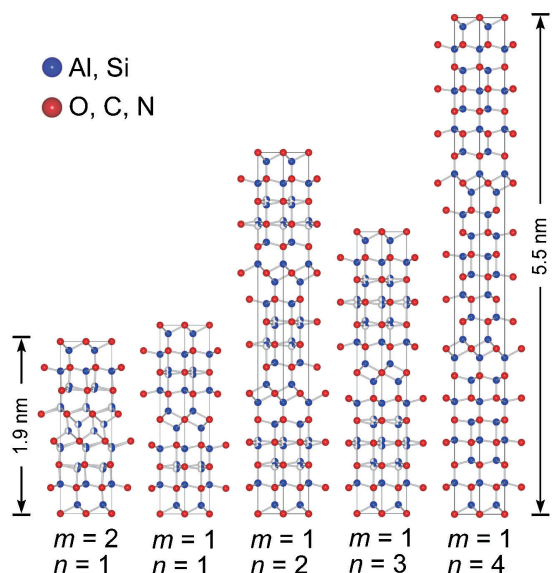

Fig. 7. Atomic configurations in $(\mathrm{Al}, \mathrm{Si})_{4 m+n}(\mathrm{O}, \mathrm{C}, \mathrm{N})_{3 m+n}$ with $1 \leq$ $m \leq 2$ and $1 \leq n \leq 4$.

presented for a series of aluminum carbonitrides of $\mathrm{Al}_{5} \mathrm{C}_{3} \mathrm{~N}$, $\mathrm{Al}_{6} \mathrm{C}_{3} \mathrm{~N}_{2}, \mathrm{Al}_{7} \mathrm{C}_{3} \mathrm{~N}_{3}$ and $\mathrm{Al}_{8} \mathrm{C}_{3} \mathrm{~N}_{4}{ }^{45}$ ) All of these carbides and carbonitrides are characterized by the layered structures made up of two types of layers. One is an $\left[(\mathrm{Al}, \mathrm{Si})_{4}(\mathrm{C}, \mathrm{N})_{4}\right]$ unit layer (denoted by $A$ ), consisting of an $\left[(\mathrm{Al}, \mathrm{Si})_{2}(\mathrm{C}, \mathrm{N})_{2}\right]$ double layer of $(\mathrm{Al}, \mathrm{Si})(\mathrm{C}, \mathrm{N})_{4}$ tetrahedra surrounded by two $\left[(\mathrm{Al}, \mathrm{Si})(\mathrm{C}, \mathrm{N})_{2}\right]$ single layers of $(\mathrm{Al}, \mathrm{Si})(\mathrm{C}, \mathrm{N})_{4}$ tetrahedra. The other is an $\left[(\mathrm{Al}, \mathrm{Si})(\mathrm{C}, \mathrm{N})_{2}\right]$ single layer (denoted by $B)$ of $(\mathrm{Al}, \mathrm{Si})(\mathrm{C}, \mathrm{N})_{4}$ tetrahedra. The crystal structures of $\mathrm{Al}_{4} \mathrm{Si}_{3} \mathrm{C}_{6}$ and $\mathrm{Al}_{7} \mathrm{C}_{3} \mathrm{~N}_{3}$ are built up of alternately stacking two types of layers with the sequence of $\angle B B A B B B A B>$ (space group $P 6_{3} m c$ and $Z=2$ ). With the rhombohedral structures of $\mathrm{Al}_{4} \mathrm{Si}_{4} \mathrm{C}_{7}$ and $\mathrm{Al}_{8} \mathrm{C}_{3} \mathrm{~N}_{4}$, the common stacking sequence is $<B B A B B B B A B B B B A B B>$ (space group $R 3 m$ and $Z=3$ ). The crystal structures of the other aluminosilicon carbides and aluminum carbonitrides are also made up of the combinations of $A$ and $B$ layers with the stacking sequences of $\angle B A B A>$ (space group $P 6_{3} m c$ and $Z=2$ ) for $\mathrm{Al}_{4} \mathrm{SiC}_{4}$ and $\mathrm{Al}_{5} \mathrm{C}_{3} \mathrm{~N}$, and $\angle B A B B A B B A B>$ (space group $R 3 m$ and $Z=3$ ) for $\mathrm{Al}_{4} \mathrm{Si}_{2} \mathrm{C}_{5}$ and $\mathrm{Al}_{6} \mathrm{C}_{3} \mathrm{~N}_{2}$. The crystal structure of $\mathrm{Al}_{8} \mathrm{SiC}_{7}$ is still uncertain.

In the system $\mathrm{Al}-\mathrm{Si}-\mathrm{O}-\mathrm{C}-\mathrm{N}$, we have discovered and structurally characterized the five types of new aluminosilicon oxycarbonitrides (Fig. 7), the general formula of which is expressed by $(\mathrm{Al}, \mathrm{Si})_{4 m+n}(\mathrm{O}, \mathrm{C}, \mathrm{N})_{3 m+n}(1 \leq m \leq 2,1 \leq n \leq 4) .{ }^{46)-50)}$ These oxycarbonitrides are made up of merohedral twin domains consisting of $A$-type $\left[(\mathrm{Al}, \mathrm{Si})_{4}(\mathrm{O}, \mathrm{C}, \mathrm{N})_{4}\right]$ unit layer and $B$-type $\left[(\mathrm{Al}, \mathrm{Si})(\mathrm{O}, \mathrm{C}, \mathrm{N})_{2}\right]$ single layer. With $(\mathrm{Al}, \mathrm{Si})_{5}(\mathrm{O}, \mathrm{C}, \mathrm{N})_{4}$ (space group $P 6_{3} / m m c$ and $Z=2$ ), the stacking sequences within individual domains are $\angle A B A B>$ and/or $\angle B A B A\rangle$, indicating that the atom arrangements of these domains are very similar to those of $\mathrm{Al}_{5} \mathrm{C}_{3} \mathrm{~N}$ (Fig. 8) ${ }^{47), 49)}$ Thus, this compound can be regarded as being homeotypic to $\mathrm{Al}_{5} \mathrm{C}_{3} \mathrm{~N}$. The layer stacking sequences are $<B A B B A B B A B>,<B B A B B A B B A>$ and/or $\angle A B B A B B A B B>$ for the three types of domains of $(\mathrm{Al}, \mathrm{Si})_{6}(\mathrm{O}, \mathrm{C}, \mathrm{N})_{5}$ (space group $R \overline{3} m$ and $Z=3$ ), which is homeotypic to $\mathrm{Al}_{6} \mathrm{C}_{3} \mathrm{~N}_{2}{ }^{48)}$ In a similar manner, the layered oxycarbonitrides with the chemical formulas $(\mathrm{Al}, \mathrm{Si})_{7}(\mathrm{O}, \mathrm{C}, \mathrm{N})_{6}$ and $(\mathrm{Al}, \mathrm{Si})_{8}(\mathrm{O}, \mathrm{C}, \mathrm{N})_{7}$ are also homeotypic to, respectively, $\mathrm{Al}_{7} \mathrm{C}_{3} \mathrm{~N}_{3}$ and $\mathrm{Al}_{8} \mathrm{C}_{3} \mathrm{~N}_{4}{ }^{50)}$ The stacking sequence within the unit cell of $(\mathrm{Al}, \mathrm{Si})_{7}(\mathrm{O}, \mathrm{C}, \mathrm{N})_{6}$ was $\angle B A B B B A B B>$, $<B B A B B B A B>,<B B B A B B B A>$ and $/$ or $\angle A B B B A B B B>$. The detailed atom arrangement in $(\mathrm{Al}, \mathrm{Si})_{8}(\mathrm{O}, \mathrm{C}, \mathrm{N})_{7}$ is still uncertain. ${ }^{50)}$ The dimensions of the domains would be within the coherence range of X-rays, hence the crystal structures were successfully represented by the split-atom models. 
(a)

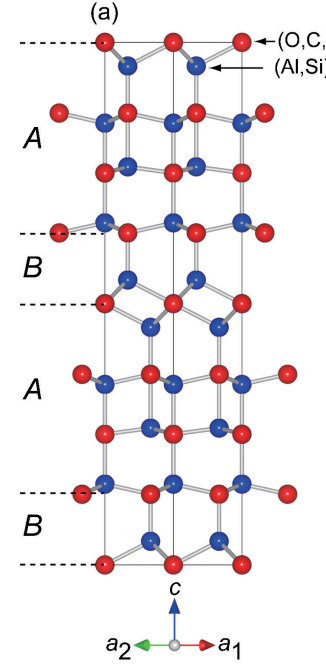

(b)

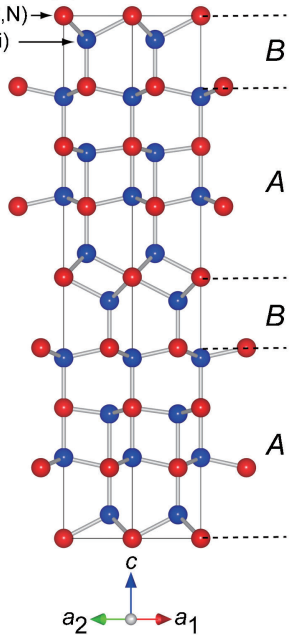

Fig. 8. Crystal structures of the two orientation states of $(\mathrm{Al}, \mathrm{Si})_{5}$ $(\mathrm{O}, \mathrm{C}, \mathrm{N})_{4}$ viewed along [110], showing the crystal structures being made up of two types of layers $A$ and $B$. The two structural configurations (a) and (b) are related by the pseudo-symmetry inversion.

\subsection{Determination of disordered atom arrange- ments in five types of SiAION polytypoids}

The SiAlON polytypoids have been well recognized from about 40 years ago since Jack (1976) has published a review paper on the phase stability in the quaternary system $\mathrm{Si}_{3} \mathrm{~N}_{4}-\mathrm{SiO}_{2}-\mathrm{Al}_{2} \mathrm{O}_{3}-$ AlN. ${ }^{51)}$ The polytypoids have the general formula $(\mathrm{Si}, \mathrm{Al})_{m^{-}}$ $(\mathrm{O}, \mathrm{N})_{m+1}(m=4,5,6,7$ and 9$)$ and are, in the notation of Ramsdell, ${ }^{52)}$ denoted as $2 m H$ ( $m$ even, space group $P 6_{3} / m m c$ and $Z=2$ ) and $3 m R$ ( $m$ odd, space group $R \overline{3} m$ and $Z=3$ ). We determined the crystal structures of $8 H(m=4), 15 R(m=5), 12 H$ $(m=6), 21 R(m=7)$ and $27 R(m=9)$ to clarify the disordered atom arrangements of all these polytypoids (Fig. 9). ${ }^{53)-58)} \mathrm{We}$ adopted the recent XRPD techniques such as MEM and MPF methods to disclose the structural details by the three-dimensional EDDs. The crystal structures of the SiAlON polytypoids necessarily showed the disordering of $(\mathrm{Si}, \mathrm{Al})$ sites. Hence, we constructed the split-atom models that are consistent with the threedimensional EDDs. In our previous studies on the oxycarbonitrides in the Al-Si-O-C-N system, these compounds were found to be composed of several domains that are related by pseudosymmetry inversion. ${ }^{46)-50)}$ In a similar manner, we interpreted each of the disordered crystal structures of SiAlON polytypoids to be a statistical average of several structural configurations related by merohedral twinning.

The crystal structure of $15 R$-SiAlON, for example, is trigonal with the unit-cell dimensions of $a=0.30133 \mathrm{~nm}$ and $c=4.1862$ $\mathrm{nm}^{55)}$ The structural model shows seven independent sites in the unit cell. They are four ( $\mathrm{Si}, \mathrm{Al})$ sites at Wyckoff positions $3 a$ $((\mathrm{Si}, \mathrm{Al}) 1)$ and $6 c((\mathrm{Si}, \mathrm{Al}) 2 \mathrm{~A},(\mathrm{Si}, \mathrm{Al}) 2 \mathrm{~B}$ and $(\mathrm{Si}, \mathrm{Al}) 3)$, and three $(\mathrm{O}, \mathrm{N})$ sites at $6 c$ [Fig. 10(a)]. Since the distance of (Si,Al)2A$(\mathrm{Si}, \mathrm{Al}) 2 \mathrm{~B}(\approx 0.085 \mathrm{~nm})$ is unusually short, these $6 c$ sites are regarded as the split sites of the same symmetry site of $6 c$. We successfully extracted three types of ordered atom arrangements, termed I, II and III [Figs. 10(b)-10(d)], from the parent disordered structural model. In the ordered structural configurations, there are vacant sites between the two oxygen layers, which correspond to the vacant cation sheet of the ordered models. The atom-arrangement models of not only $15 R$-SiAlON but also $8 H-, 12 H-, 21 R$ - and $27 R$-SiAlON are probably for the

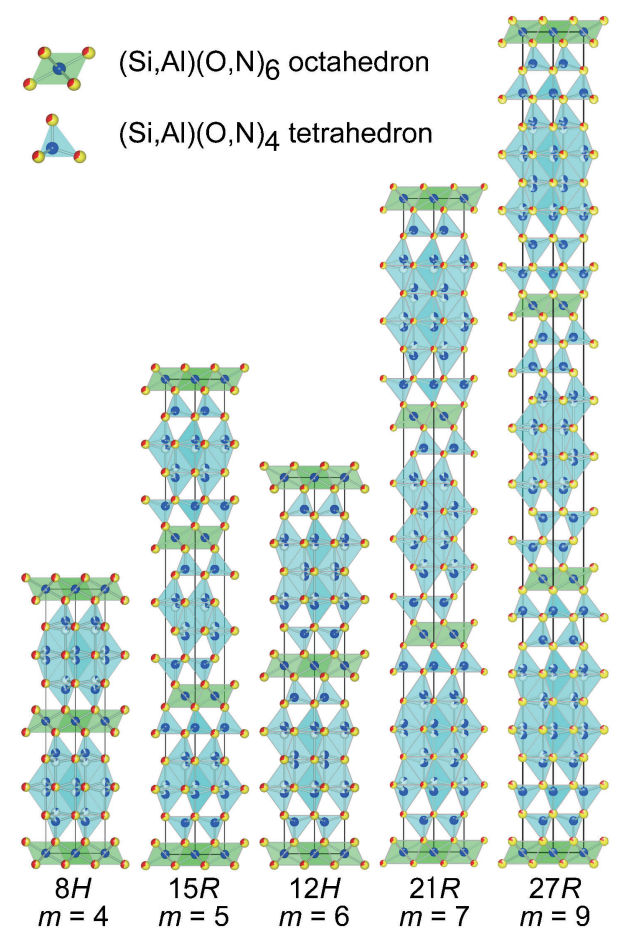

Fig. 9. Atomic configurations in SiAlON polytypoids of $(\mathrm{Si}, \mathrm{Al})_{m^{-}}$ $(\mathrm{O}, \mathrm{N})_{m+1}$ with $m=4(8 H), 5(15 R), 6(12 H), 7(21 R)$ and $9(27 R)$. (a)

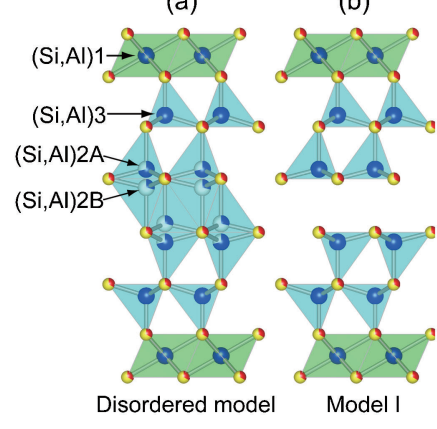

(c)

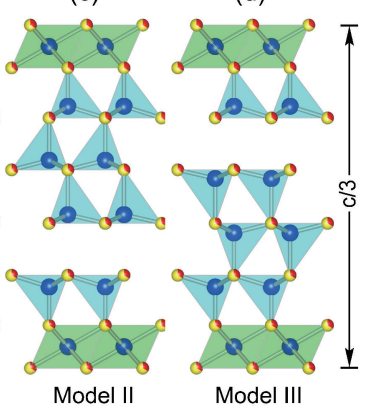

Fig. 10. Parts of the (a) disordered and (b)-(d) ordered atom arrangements of $15 R-\mathrm{SiAlON}$ viewed along [110]. Atomic configurational model I in (b) with the space group $R \overline{3} \mathrm{~m}$. The two models II in (c) and III in (d) with the space group $R 3 \mathrm{~m}$. The two atomic configurations of II and III are related by the pseudo-symmetry inversion.

domains with the size distribution ranging from the unit-cell size to the coherence range of X-rays. These domains with ordered structures would be combined randomly and construct the whole disordered structure.

With $15 R$-SiAlON, the neighboring $(\mathrm{Si}, \mathrm{Al}) 2 \mathrm{~B}$ atoms are absent in the ordered models because the $(\mathrm{Si}, \mathrm{Al}) 2 \mathrm{~B}-(\mathrm{Si}, \mathrm{Al}) 2 \mathrm{~B}$ distance $(=0.2415 \mathrm{~nm})$ is unusually short as compared with the $(\mathrm{Si}, \mathrm{Al}) 2 \mathrm{~A}-(\mathrm{Si}, \mathrm{Al}) 2 \mathrm{~B}(=0.3070 \mathrm{~nm})$ and $(\mathrm{Si}, \mathrm{Al}) 2 \mathrm{~A}-(\mathrm{Si}, \mathrm{Al}) 2 \mathrm{~A}$ $(=0.3806 \mathrm{~nm})$ distances [Figs. 10(b)-10(d).$^{55)}$ The atom arrangement of model I is centrosymmetric (space group $R \overline{3} \mathrm{~m}$ ), and those of the other two models (II and III) are noncentrosymmetric (space group $R 3 \mathrm{~m}$ ). The latter two structural configurations are thus related by merohedral twinning. The $g$-values of the disordered structural model are characterized by $[g((\mathrm{Si}, \mathrm{Al}) 2 \mathrm{~A})$ : $g((\mathrm{Si}, \mathrm{Al}) 2 \mathrm{~B})]=[5: 2]$. From these values we estimated the abundance $(A)$ of each domain with the ordered structure by the following procedure. We defined the numbers of cation site $M$ in 
the unit cell of each domain $\mathrm{d}_{m}$ ( $m=\mathrm{I}$, II and III) as $N(M)_{m}$. The total number of $M$ site in the unit cell of the disordered structural model is determined by $\Sigma\left\{A\left(\mathrm{~d}_{m}\right) \times N(M)_{m}\right\}$. Hence, we obtain $[g((\mathrm{Si}, \mathrm{Al}) 2 \mathrm{~A}): g((\mathrm{Si}, \mathrm{Al}) 2 \mathrm{~B})]=\left[\Sigma\left\{A\left(\mathrm{~d}_{m}\right) \times N((\mathrm{Si}, \mathrm{Al}) 2 \mathrm{~A})_{m}\right\}\right.$ : $\left.\Sigma\left\{A\left(\mathrm{~d}_{m}\right) \times N((\mathrm{Si}, \mathrm{Al}) 2 \mathrm{~B})_{m}\right\}\right]$. The simplest and most plausible $A\left(\mathrm{~d}_{m}\right)$-values satisfying the equation of $\left[\Sigma\left\{A\left(\mathrm{~d}_{m}\right) \times N((\mathrm{Si}, \mathrm{Al})\right.\right.$ $\left.\left.2 \mathrm{~A})_{m}\right\}: \Sigma\left\{A\left(\mathrm{~d}_{m}\right) \times N((\mathrm{Si}, \mathrm{Al}) 2 \mathrm{~B})_{m}\right\}\right]=[5: 2]$ are $\left[A\left(\mathrm{~d}_{\mathrm{I}}\right): A\left(\mathrm{~d}_{\mathrm{II}}\right):\right.$ $\left.A\left(\mathrm{~d}_{\mathrm{III}}\right)\right]=[3: 2: 2]$. This implies that the formation abundance of domain $\mathrm{I}$ is 1.5 times larger than that of the other domains. The unequal abundance between the centrosymmetric and noncentrosymmetric domains still remains enigmatic. The more detailed investigation is necessary to clarify the formation mechanism of the disordered structures of the polytypoids.

\subsection{Synthesis and disordered crystal structure of $\mathrm{Al}_{3} \mathrm{O}_{3.5} \mathrm{C}_{0.5}$}

In the system $\mathrm{Al}_{2} \mathrm{O}_{3}-\mathrm{Al}_{4} \mathrm{C}_{3}$, there are three intermediate compounds established; they are $\mathrm{Al}_{3} \mathrm{O}_{3.5} \mathrm{C}_{0.5}, \mathrm{Al}_{4} \mathrm{O}_{4} \mathrm{C}$ and $\mathrm{Al}_{2} \mathrm{OC}$. ${ }^{59), 60)}$ We have determined the crystal structure of $\mathrm{Al}_{3} \mathrm{O}_{3.5} \mathrm{C}_{0.5}$ (space group $R \overline{3} m$ and $Z=3$ ), which was satisfactorily represented by the split-atom model. The crystal structure can be regarded as the layered structure, consisting of the $\alpha-\mathrm{Al}_{2} \mathrm{O}_{3}$-type $\left[\mathrm{AlO}_{2}\right]$ single layers (denoted by $C$ ) separated by the $\left[\mathrm{Al}_{2}(\mathrm{O}, \mathrm{C})_{4}\right]$ unit layers (denoted by $D$ ). The atom arrangement of the latter layer is described in terms of a three dimensional network of $\left[\mathrm{Al}(\mathrm{O}, \mathrm{C})_{4}\right]$ tetrahedra which are associated by sharing corners. These two types of layers are alternately stacked in the $c$-axis direction with a sequence $<C D C D C D>$ in the unit cell to form the three dimensional structure.

The dark-field TEM showed the crystal to be composed of several APDs that are related by the unit-lattice translation (refer to Fig. 6 in the original manuscript). ${ }^{60}$ The most plausible explanation for the formation of APD structure is that the phase transition from the high-symmetry $(\mathrm{H})$ phase to the low-symmetry (L) phase occurred on cooling. The H-to-L phase transition should be accompanied by the loss of translational symmetry. The size of the unit cell is increased by 4 during transition since the unit-cell dimensions of the H-phase (cell dimensions of $a_{\mathrm{H}}$ and $c_{\mathrm{H}}$ ) and those of the L-phase (cell dimensions of $a_{\mathrm{L}}$ and $c_{\mathrm{L}}$ ) are related by $a_{\mathrm{L}} \approx 2 \times a_{\mathrm{H}}$ and $c_{\mathrm{L}} \approx c_{\mathrm{H}}{ }^{60)}$ Thus, the number of variants possible to produce during the phase transition is 4 . These four variants (I, II, III and IV) are related across the APD boundaries by the displacement vectors $1 / 2[100]_{\mathrm{L}}$ for variants $\mathrm{I}$ and II, $1 / 2[010]_{\mathrm{L}}$ for variants I and III and $1 / 2[110]_{\mathrm{L}}$ for variants I and IV as schematically illustrated in Fig. 11. We actually observed the APDs that are related by the displacement vector $1 / 2[010]{ }^{60)}$ The structural model determined by XRD is probably of the average crystal structure of the L-phase.

\section{Conclusion}

We succeeded in the syntheses of new inorganic materials and subsequent determination of their crystal structures and intracrystalline microtextures using the complementary methods of diffractometry and microscopy. We discovered the Si-deficient LSO and successfully prepared its highly $c$-axis-oriented polycrystal by the reactive diffusion technique, which showed the significantly increased oxide-ion conductivity along the common $c$-axis. We demonstrated, for the first time, the thermoelectric conversion property of the layered carbides in the system $\mathrm{Zr}-\mathrm{Y}-$ $\mathrm{Si}-\mathrm{Al}-\mathrm{C}$, and revealed the design guidelines to achieve the high performance as $n$-type thermoelectric conversion materials. We expect in the future the realization of as-yet-unrecognized innovative functions for the other layered compounds in the systems

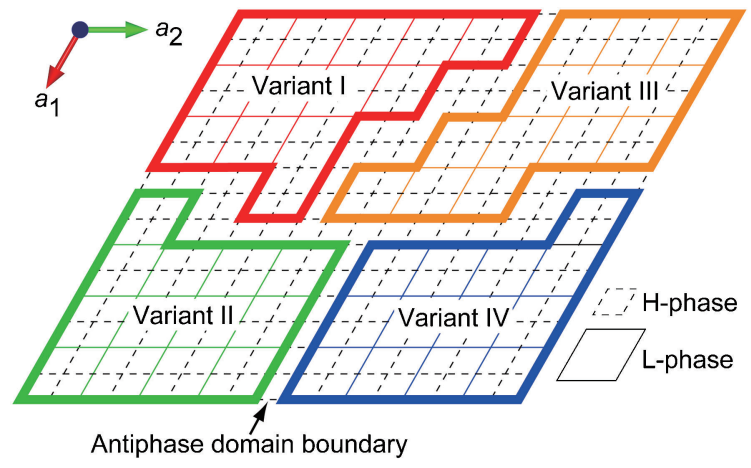

Fig. 11. Schematic illustration of antiphase domain structure in $\mathrm{Al}_{3} \mathrm{O}_{3.5} \mathrm{C}_{0.5}$. The variants $\mathrm{I}$ and II are related by $1 / 2[100]_{\mathrm{L}}$, those of I and III by $1 / 2[010]_{\mathrm{L}}$ and those of I and IV by $1 / 2[110]_{\mathrm{L}}$.

$\mathrm{Al}-\mathrm{Si}-\mathrm{O}-\mathrm{C}-\mathrm{N}, \mathrm{Si}-\mathrm{Al}-\mathrm{O}-\mathrm{N}$ and $\mathrm{Al}-\mathrm{O}-\mathrm{C}$ by focusing on their characteristic crystal structures.

Acknowledgment The author wishes to acknowledge Professor H. Nakano, Toyohashi University of Technology, and Associate Professor T. Asaka, Nagoya Institute of Technology, for valuable discussion in the field of transmission electron microscopy.

\section{References}

1) S. Nakayama, T. Kageyama, H. Aono and Y. Sadaoka, J. Mater. Chem., 5, 1801-1805 (1995).

2) S. Nakayama and M. Sakamoto, J. Eur. Ceram. Soc., 18, 1413-1418 (1998).

3) L. D. Hicks and M. S. Dresselhaus, Phys. Rev. B, 47, 1272712731 (1993).

4) L. D. Hicks and M. S. Dresselhaus, Phys. Rev. B, 47, 1663116634 (1993).

5) L. D. Hicks, T. C. Harman and M. S. Dresselhaus, Appl. Phys. Lett., 63, 3230-3232 (1993).

6) K. Koumoto, H. Koduka and W.-S. Seo, J. Mater. Chem., 11, 251-252 (2001).

7) M. Yasukawa, K. Ikeuchi, T. Kono, K. Ueda and H. Hosono, J. Appl. Phys., 98, 013706 (2005).

8) T. Mori and T. Nishimura, J. Solid State Chem., 179, 29082915 (2006).

9) G. L. Nord, Jr., "Imaging Transformation-Induced Microstructures", In Minerals and Reactions at the Atomic Scale: Transmission Electron Microscopy; P. R. Buseck, Ed.; Mineralogical Society of America: Washington, DC (1992) pp. 455508.

10) M. Takata, E. Nishibori and M. Sakata, Z. Kristallogr., 216, 71-86 (2001).

11) F. Izumi, Solid State Ionics, 172, 1-6 (2004).

12) H. M. Rietveld, Acta Crystallogr., 22, 151-152 (1967).

13) F. Izumi, S. Kumazawa, T. Ikeda, W.-Z. Hu, A. Yamamoto and K. Oikawa, Mater. Sci. Forum, 378-381, 59-64 (2001).

14) F. Izumi and K. Momma, Solid State Phenom., 130, 15-20 (2007).

15) K. Momma, T. Ikeda, A. A. Belik and F. Izumi, Powder Diffr., 28, 184-193 (2013).

16) K. Momma and F. Izumi, J. Appl. Cryst., 44, 1272-1276 (2011).

17) I. D. Muir, "Microscopy: Transmitted Light", in Physical Methods in Determinative Mineralogy, Ed. by J. Zussman, Academic Press, London, U.K. (1977) pp. 35-108.

18) K. Fukuda, T. Asaka, S. Hara, M. Oyabu, A. Berghout, E. Béchade, O. Masson, I. Julien and P. Thomas, Chem. Mater., 25, 2154-2162 (2013).

19) K. Fukuda, T. Asaka, R. Hamaguchi, T. Suzuki, H. Oka, A. Berghout, E. Béchade, O. Masson, I. Julien, E. Champion and 
P. Thomas, Chem. Mater., 23, 5474-5483 (2011).

20) K. Fukuda, T. Asaka, N. Ishizawa, H. Mino, D. Urushihara, A. Berghout, E. Béchade, O. Masson, I. Julien and P. Thomas, Chem. Mater., 24, 2611-2618 (2012).

21) T. Kimura, M. H. Holmes and R. E. Newnham, J. Am. Ceram. Soc., 65, 223-226 (1982).

22) H. Kaga, Y. Kinemuchi, H. Yilmaz, K. Watari, H. Nakano, H. Nakano, S. Tanaka, A. Makiya, Z. Kato and K. Uematsu, Acta Mater., 55, 4753-4757 (2007).

23) P. H. Xiang, Y. Kinemuchi, K. Watari, H. Ishiguro, F. Cao and X. L. Dong, J. Mater. Res., 21, 1830-1835 (2006).

24) K. Fukuda, J. Crystallogr. Soc. Jpn, 56, $43-48$ (2014).

25) M. Th. Gesing and W. Jeitschko, J. Solid State Chem., 140, 396-401 (1998).

26) K. Fukuda, S. Mori and S. Hashimoto, J. Am. Ceram. Soc., 88, 3528-3530 (2005).

27) E. Parthe and B. Chabot, Acta Crystallogr., C44, 774-775 (1988).

28) A. O. Tsokol, O. I. Bodak, E. P. Marusin and M. G. Baivel'man, Kristallografiya, 31, 791-792 (1986).

29) M. Th. Gesing, R. Poettgen, W. Jeitschko and U. Wortmann, J. Alloys Compd., 186, 321-331 (1992).

30) M. Th. Gesing and W. Jeitschko, Z. Naturforsch., 50b, 196200 (1995).

31) K. Fukuda and M. Hisamura, J. Am. Ceram. Soc., 90, 32993302 (2007).

32) K. Fukuda, M. Hisamura, T. Iwata, N. Tera and K. Sato, J. Solid State Chem., 180, 1809-1815 (2007).

33) K. Fukuda, M. Hisamura, Y. Kawamoto and T. Iwata, J. Mater. Res., 22, 2888-2894 (2007).

34) K. Fukuda, M. Hisamura, T. Iwata, S. Hashimoto and H. Nakano, J. Am. Ceram. Soc., 91, 1342-1345 (2008).

35) T. Iwata, E. Hattori, S. Hashimoto and K. Fukuda, J. Am Ceram. Soc., 91, 2713-2715 (2008).

36) T. Iwata, K. Sugiura, S. Hashimoto and K. Fukuda, J. Am Ceram. Soc., 91, 3758-3761 (2008).

37) K. Sugiura, T. Iwata, H. Yoshida, S. Hashimoto and K. Fukuda, J. Solid State Chem., 181, 2864-2868 (2008).

38) K. Sugiura, T. Iwata, H. Nakano and K. Fukuda, J. Solid State Chem., 182, 1619-1623 (2009).

39) M. Yashima, K. Fukuda, Y. Tabira and M. Hisamura, Chem.
Phys. Lett., 451, 48-52 (2008)

40) R. J. Oscroft, P. Korgul and D. P. Thompson, British Ceramic Proc., 42, 33-47 (1989).

41) V. J. Barczak, J. Am. Ceram. Soc., 44, 299 (1961).

42) Z. Inoue, Y. Inomata, H. Tanaka and H. Kawabata, J. Mater. Sci., 15, 575-580 (1980).

43) J. Schoennahl, B. Willer and M. J. Daire, J. Solid State Chem., 52, 163-173 (1984).

44) B. L. Kidwell, L. L. Oden and R. A. McCune, J. Appl. Cryst., 17, 481-482 (1984).

45) G. A. Jefeerey and V. Y. Wu, Acta Crystallogr., 20, 538-547 (1966).

46) T. Iwata, M. Kaga, H. Nakano and K. Fukuda, J. Solid State Chem., 182, 2252-2260 (2009).

47) M. Kaga, T. Iwata, H. Nakano and K. Fukuda, J. Solid State Chem., 183, 636-642 (2010).

48) M. Kaga, D. Urushihara, T. Iwata, K. Sugiura, H. Nakano and K. Fukuda, J. Solid State Chem., 183, 2183-2189 (2010).

49) H. Inuzuka, M. Kaga, D. Urushihara, H. Nakano, T. Asaka and K. Fukuda, J. Solid State Chem., 183, 2570-2575 (2010).

50) D. Urushihara, M. Kaga, T. Asaka, H. Nakano and K. Fukuda, J. Solid State Chem., 184, 2278-2284 (2011).

51) K. H. Jack, J. Mater. Sci., 11, 1135-1158 (1976).

52) E. Parthé, "Crystal Chemistry of Tetrahedral Structures", Gordon and Breach Science Publishers, New York (1964) p. 109.

53) T. Asaka, T. Kudo, H. Banno, S. Funahashi, N. Hirosaki and K. Fukuda, Powder Diffr., 28, 171-177 (2013).

54) T. Asaka, H. Banno, S. Funahashi, N. Hirosaki and K. Fukuda, J. Solid State Chem., 204, 21-26 (2013).

55) H. Banno, T. Hanai, T. Asaka, K. Kimoto and K. Fukuda, J. Solid State Chem., 211, 124-129 (2014).

56) H. Banno, T. Asaka and K. Fukuda, J. Solid State Chem., 213, 169-175 (2014).

57) H. Banno, T. Hanai, T. Asaka, K. Kimoto and K. Fukuda, Powder Diffr., 29, 318-324 (2014).

58) H. Banno, T. Asaka and K. Fukuda, J. Ceram. Soc. Japan, 122, 281-287 (2014).

59) C. Qui and R. Z. Metselaar, Metallkd., 86, 198-205 (1995).

60) T. Asaka, R. Kotani, T. Kudo, H. Yoshida and K. Fukuda, Inorg. Chem., 52, 2648-2653 (2013).

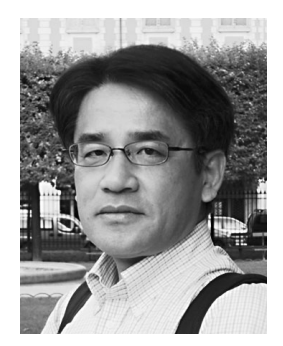

Koichiro Fukuda received his BS (1984), MS (1986), and Dr. Sci. (1992) degrees in Mineralogy from the University of Tokyo, Japan. In 1986, he became a research associate at Nagoya Institute of Technology. From 1997 to 1998, he was a research fellow in Department of Chemistry at the University of Aberdeen, UK. He has been a Professor of Materials Science and Engineering at Nagoya Institute of Technology since 2008. 